\title{
Somatostatin-like immunoreactivity in the cerebrospinal fluid of patients with Parkinson's disease and its relation to dementia
}

\author{
JUKKA JOLKKONEN, HILKKA SOININEN, TOIVO HALONEN, AARNE YLINEN, \\ VEIKKO LAULUMAA, MARKKU LAAKSO, * PAAVO RIEKKINEN
}

From the Department of Neurology and Department of Medicine, ${ }^{*}$ University of Kuopio, Kuopio, Finland

SUMMARY Acetylcholinesterase, somatostatin-like immunoreactivity, and homovanillic acid levels were measured in the cerebrospinal fluid of 36 patients with early stages of Parkinson's disease and in 19 control patients. In patients with Parkinson's disease the levels of somatostatinlike immunoreactivity were lower than in the controls $(p<0.01)$; these values were lowest in the demented Parkinsonian patients. Concentrations of homovanillic acid were also significantly lower in Parkinsonian patients $(p<0.05)$. In contrast, no changes were observed in the acetylcholinesterase activity of patients with Parkinson's disease. The reduced somatostatin-like immunoreactivity in CSF agrees with previous post-mortem studies and indicates that Parkinson's disease and Alzheimer's disease may have some neurochemical features in common.

According to the literature about $20 \%$ of the patients with Parkinson's disease probably have dementia. ${ }^{1}$ Neuropathological findings of the brain show that some demented Parkinsonian patients have histological changes characteristic of Alzheimer's disease. ${ }^{2-4}$ Upon neuropathological examination of the brain, however, some demented Parkinsonian patients are found to have no Alzheimer type changes. ${ }^{56}$ Reduced cell counts of the nucleus basalis of Meynert, which gives rise to cortical cholinergic innervation, have been shown in both Alzheimer's disease and Parkinson's disease. ${ }^{78}$ In numerous studies patients with Alzheimer's disease have been found to have reduced cortical choline acetyltransferase (ChAT), which is correlated with the severity of dementia and the number of senile plaques. ${ }^{910}$ Reduced cortical ChAT activities have been demonstrated in demented Parkinsonian patients with and without brain pathology of the Alzheimer type. ${ }^{6} 1112$

In addition to the cholinergic deficit in Alzheimer's disease and Parkinson's disease, recent studies have

Address for reprint requests: PJ Riekkinen, Department of Neurology, University of Kuopio, PO Box 6, 70211 Kuopio, Finland.

Received 30 July 1985 and in final revised form 19 February 1986. Accepted 24 February 1986 shown disturbance of the somatostatin system. ${ }^{1314}$ In Parkinson's disease reduced somatostatin levels have been found in the cortex and hippocampus and also in CSF. ${ }^{1415}$ However, the somatostatin levels were also reduced in CSF of patients with Alzheimer's disease, Huntington's chorea, multiple sclerosis and those with depression. ${ }^{16-19}$

We recently demonstrated dementia-related decrease of cholinesterase activity and somatostatinlike immunoreactivity in CSF of patients with Alzheimer's disease. ${ }^{16}$ The purpose of this study was to measure these levels in CSF from patients with Parkinson's disease and to examine how they are related to dementia. In addition, we measured homovanillic acid as a marker of the dopaminergic system.

\section{Patients and methods}

\section{Patients and controls}

Thirty-six patients with early stages of classical Parkinson's disease (18 female, 18 male) aged $69 \pm 9$ years (mean \pm SD), range 44-81 years, participated after giving informed consent in this study. Duration of the disease ranged from 6 months to 10 years (mean 2.9 years). The disability stage of Parkinson's disease was recorded according to Hoehn and Yahr. ${ }^{20}$ The severity of dementia was estimated using the dementia staging scale of Hughes et al. ${ }^{21}$ According to this scale, 10 patients had no signs of dementia, 19 had slight memory disorders (questionable dementia), and seven had mild to moderate dementia and met DSM III criteria. Symptoms of depression were assessed by Hamilton's rating 
scale. ${ }^{22}$ Eighteen of the patients were receiving anticholinergics, one patient was receiving levodopa combined with an inhibitor of dopa decarboxylase, and 17 patients were without drug treatment for Parkinson's disease. As controls we examined 19 patients (nine female, 10 male), aged $61 \pm 10$ years (mean $\pm S D$ ), range $38-78$ years, who required diagnostic lumbar puncture for previous transient ischaemic attack, vertigo, headache, polyneuropathy or amyotrophic lateral sclerosis. According to clinical criteria none of these patients had signs of dementia, depression, multiple sclerosis or Parkinson's disease.

\section{Samples}

At 8-10 am a standard amount of lumbar CSF was obtained from the patients as they lay in a recumbent position. The samples were frozen immediately and stored at $-80^{\circ} \mathrm{C}$ until assayed. The tubes for determinations of somatostatin-like immunoreactivity contained Aprotinin $(700 \mathrm{KIU} / \mathrm{ml})$ as enzyme inhibitor.

\section{Methods}

Acetylcholinesterase (AChE) activity was determined according to a modification of the method developed by Ellman et al. ${ }^{23}$ The reaction mixture $(3.0 \mathrm{ml})$ in the total cholinesterase measurements consisted of final concentrations of $0.09 \mathrm{M}$ phosphate buffer (final $\mathrm{pH} 7.6$ ), $0.84 \mathrm{mM}$ 5.5-dithiobis-(2-nitrobenzoic acid), $0.5 \mathrm{mM}$ acetylthiocholine iodide as substrate, and $0.5 \mathrm{ml}$ diluted CSF $(1+4$ with $\mathrm{H}_{2} \mathrm{O}$ ). A specific acetylcholinesterase inhibitor, BW284C51 $(5.6 \mu \mathrm{M})$, was used to inhibit true AChE and the residual activity was subtracted from the cholinesterase activity to obtain acetylcholinesterase activity. The mixtures were incubated at $+37^{\circ} \mathrm{C}$ for $20 \mathrm{~min}$, and the yellow colour formed was read at $412 \mathrm{~nm}$. Colour formation was linear for at least $30 \mathrm{~min}$.

The somatostatin-like immunoreactivity (SLI) was determined using a commercial RIA kit (Immunonuclear Corporation, Minnesota, USA). ${ }^{16}$ CSF samples $(600 \mu l)$ were extracted with acetone-petroleum ether. After evaporation, the residue was redissolved in $200 \mu \mathrm{l}$ assay buffer for radioimmunoassay. For increased sensitivity, the assay was run disequilibrated; $200 \mu \mathrm{l}$ standard or sample and $100 \mu \mathrm{l}$ antiserum were incubated for $20 \mathrm{~h}$ at $+4^{\circ} \mathrm{C}$, after which $100 \mu \mathrm{l}$ tracer was added and incubation was continued for $24 \mathrm{~h}$.

Homovanillic acid was measured by high performance liquid chromatography (HPLC) using electrochemical detection. CSF $(300 \mu l)$ was mixed with $100 \mu l$ of the internal standard mixture, $200 \mathrm{nM}$ 3-methoxy-4-hydroxy-phenylethanol in $1 \mathrm{M} \mathrm{HClO}_{4}$ containing $0.1 \mathrm{M} \mathrm{Na} \mathrm{Na}_{2} \mathrm{~S}_{2} \mathrm{O}_{5}$ and $0.01 \mathrm{M} \mathrm{Na}_{2}$ EDTA. The samples were centrifuged, and $25 \mu \mathrm{l}$ of the supernatant was injected into a HPLC column. For separation of HVA, the method described by Mefford was used; the mixture contained $0.1 \mathrm{M}$ acetic acid with $0.1 \mathrm{M}$ citric acid and $20 \%$ methanol ( $\mathrm{pH} 4 \cdot 1)$ and had a flow rate of $1.2 \mathrm{ml} / \mathrm{min} .{ }^{24}$ Homovanillic acid was detected at a flow cell potential of $0.85 \mathrm{~V}$. The liquid chromatography system consisted of an Altex 110A pump, an Ultrasphere ODS column $(250 \times 4.6 \mathrm{~mm}, 5 \mu \mathrm{m}$ particle size), and an LC-4B electrochemical detector by BAS equipped with a glassy carbon electrode.
Table 1 Cerebrospinal fluid acetylcholinesterase $(A C h E)$, somatostatin-like immunoreactivity (SLI) and homovanillic acid (HVA) in patients with Parkinson's disease and in controls

\begin{tabular}{lrrl}
\hline & Parkinsonians & Controls & $p^{*}$ \\
\hline AChE & & & \\
$(\mathrm{nmol} / \mathrm{ml} / \mathrm{min})$ & $27.9 \pm 1.3(36)$ & $24.6 \pm 1.9(17)$ & NS \\
SLI (fmol/ml) & $9.7 \pm 0.4(35)$ & $12.5 \pm 0.7(19)$ & 0.01 \\
HVA $(\mathrm{pmol} / \mathrm{ml})$ & $173.7 \pm 13.8(34)$ & $223.7 \pm 16.0(16)$ & 0.05 \\
\hline
\end{tabular}

* Significance of difference between groups; ANCOVA, adjusted for age. Values are expressed as mean \pm SEM with number of patients in parentheses. NS $=$ not significant.

\section{Statistical methods}

The difference between the groups of Parkinsonian patients and controls was assessed by Student's two-tailed $t$ test for independent samples and analysis of covariance (ANCOVA) adjusted for age. The adjustment for age was done because there was a statistically significant difference in age between the Parkinsonians and controls.

\section{Results}

Mean levels of somatostatin-like immunoreactivity and homovanillic acid in CSF were significantly reduced in patients with Parkinson's disease. Acetylcholinesterase activity did not differ from that of the control patients (table 1). The reduction in SLI levels was most marked in the CSF of demented Parkinsonian patients (table 2). Also the values for patients with Parkinson's disease who showed no signs of dementia seemed to be lower than those for the controls. However, there were no statistically significant differences in SLI levels when the groups of Parkinsonian patients with different degree of dementia were compared with the controls or with each other (ANCOVA, adjusted for age). Similar results were obtained concerning the relation of SLI values and severity of Parkinson's disease (table 3). No difference in levels of somatostatin-like immunoreactivity, acetylcholinesterase, or homovanillic acid was found

Table 2 Somatostatin-like immunoreactivity (SLI) in CSF of patients with Parkinson's disease. Relation to severity of dementia.

\begin{tabular}{lc}
\hline & $S L I \mathrm{fmol} / \mathrm{ml}$ \\
\hline Controls & $12.5 \pm 0.7(19)$ \\
Parkinsonians & $10.4 \pm 1.0(9)$ \\
0.5 & $9.7 \pm 0.5(19)$ \\
$1+2$ & $9.0 \pm 0.9(7)$ \\
\hline
\end{tabular}

No significant differences between the groups; ANCOVA adjusted for age. The severity of dementia was estimated using the rating scale of Hughes et al ${ }^{21} ; 0=$ no signs of dementia, $0 \cdot 5=$ slight memory disorders (questionable dementia), $1+2=$ mild or moderate dementia (patients met DMS III criteria). Values are expressed as mean \pm SEM with number of patients in parentheses. 
Table 3 Somatostatin-like immunoreactivity (SLI) in CSF of patients with Parkinson's disease. Relation to stage of disability.

\begin{tabular}{lc}
\hline & SLI fmol/ml \\
\hline Controls & $12.5 \pm 0.7(19)$ \\
Parkinsonians & $11.4 \pm 1.3(8)$ \\
I & $9.4 \pm 0.4(22)$ \\
II & $8.4 \pm 0.7(5)$ \\
\hline
\end{tabular}

No significant differences between the groups; ANCOVA adjusted for age. The disability stage of Parkinson's disease (I-IV) was estimated according to Hoehn and Yahr. ${ }^{20}$ Values are expressed as mean \pm SEM with number of patients in parentheses.

between patients with Parkinson's disease who were receiving cholinergic medication and those who did not. The levels of SLI, AChE and HVA were also similar in depressed (depression scores according to Hamilton's scale $\leqslant 12$ ) and in non-depressed Parkinsonian patients (depression scores $>12$ ).

\section{Discussion}

The relationships between dementia and derangements in neurotransmitter systems have been poorly determined in Parkinson's disease. ${ }^{25}$ Previous reports have indicated cholinergic dysfunction in patients with Alzheimer's disease as well as in Parkinsonian patients with cognitive impairment. ${ }^{256}$ Although low acetylcholinesterase activities have been reported in CSF of Alzheimer patients, we could not demonstrate a significant change in this cholinergic enzyme activity in Parkinsonian patients with mild or moderate dementia compared with the controls or patients without cognitive impairment. ${ }^{1626}$ The unaffected AChE levels of demented patients with Parkinson's disease may be explained by the fact that patients in the present study were in the early stages of the disease and the cognitive impairment observed was at most moderate. AChE activity in CSF should be measured in Parkinsonian patients with more advanced disease and more severe dementia. On the other hand, the cognitive dysfunction in Parkinson's disease may be based on the disturbance of other transmitter systems than the cholinergic one.

In patients with Parkinson's disease the mean somatostatin-like immunoreactivity was reduced compared with the values for controls. These values seemed to be related also to the severity of dementia and stage of disability, although statistical significances were not found. The lowest levels of SLI were observed in patients with the most severe cognitive impairment, a finding which agrees with the post mortem data of Epelbaum et al. ${ }^{14}$ In CSF studies without neuropathological verification of diagno- sis, however, we cannot exclude the possibility that Parkinson's disease and Alzheimer's disease co-exist. Therefore the CSF results must be interpreted cautiously. Dupont et al also found low levels of somatostatin in CSF of patients with Parkinson's disease, but the relation of these values to the severity of dementia was not studied. ${ }^{15}$ However, levels of CSF somatostatin also seem to be reduced in several other degenerative diseases. ${ }^{16-18}$ Thus further studies are needed to determine the specificity and significance of somatostatin changes in CSF.

In addition to the low homovanillic acid concentrations, the affected somatostatin, methioneenkephalin and substance $P$ values in CSF strengthen the view that extensive peptidergic disorder is present in Parkinson's disease. ${ }^{1527}$ According to the CSF findings concerning somatostatin, patients with Parkinson's disease may have some neurochemical features associated with dementia that are similar to the changes found in Alzheimer's disease. Furthermore, the present findings suggest that the cholinergic system may remain more intact in Parkinson's disease than in Alzheimer's disease. This supports the hypothesis that cognitive dysfunction in Parkinson's disease and Alzheimer's disease may have different mechanisms.

We thank Miss Eija Heikkinen and Mrs Sirpa Kemppinen for their excellent technical assistance.

\section{References}

1 Brown RG, Marsden CD. How common is dementia in Parkinson's disease? Lancet 1984;ii:1262-5.

2 Alvard E, Forna LS, Kusse JA, Kauffman RJ, Rhodes JS, Goetowski CR. The pathology of Parkinsonism: a comparison of degenerations in cerebral cortex and brainstem. Adv Neurol 1979;5:175-99.

3 Hakim AM, Mathieson G. Dementia in Parkinson's disease: a neuropathological study. Neurology 1979; 29:1209-14.

4 Boller F, Mizutani T, Roessmann U, Gambetti P. Parkinson's disease: clinicopathological correlations. Ann Neurol 1980;7:329-35.

5 Heston LL. Dementia associated with Parkinson's disease: a genetic study. J Neurol Neurosurg Psychiatry 1980;43:846-8.

6 Perry RH, Tomlinson BE, Candy JM, et al. Cortical cholinergic deficit in mentally impaired Parkinsonian patients. Lancet 1983;ii:789-90.

7 Whitehouse PJ, Price DL, Clark AW, Coyle JT, DeLong MR. Alzheimer's disease: evidence for selective loss of cholinergic neurons in the nucleus basalis. Ann Neurol 1981;10:122-6.

8 Whitehouse PJ, Hedreen JC, White CL, Price DL. Basal forebrain neurons in the dementia of Parkinson's disease. Ann Neurol 1983;13:234-8.

9 Davies P, Maloney AJR. Selective loss of central choli- 
nergic neurons in Alzheimer's disease. Lancet 1976;ii: 1403.

10 Perry EK, Tomlinson BE, Blessed G, Bergmann K, Gibson PH, Perry RH. Correlation of cholinergic abnormalities with senile plaques and mental test scores in senile dementia. Br Med J 1978;2:1457-9.

11 Rubert M, Ploska A, Javoy-Agid F, Agid Y. Muscarinic binding and choline acetyltransferase activity in Parkinsonian subjects with reference to dementia. Brain Res 1982;232:129-39.

12 Dubois B, Ruberg M, Javoy-Agid F, Ploska A, Agid Y. A subcortico-cortical cholinergic system is affected in Parkinson's disease. Brain Res 1983;288:213-8.

13 Davies P, Katzman R, Terry RD. Reduced somatostatin-like immunoreactivity in cerebral cortex from cases of Alzheimer disease and Alzheimer senile dementia. Nature 1980;288:279-80.

14 Epelbaum J, Ruberg M, Moyse E, Javoy-Agid F, Dubois B, Agid Y. Somatostatin and dementia in Parkinson's disease. Brain Res 1983;278:376-9.

15 Dupont E, Christensen SE, Hansen AP, de Fine Olivarius B, Orskov H. Low cerebrospinal fluid somatostatin in Parkinson's disease: an irreversible abnormality. Neurology 1982;32:312-4.

16 Soininen HS, Jolkkonen JT, Reinikainen KJ, Halonen TO, Riekkinen PJ. Reduced cholinesterase activity and somatostatin-like immunoreactivity in the cerebrospinal fluid of patients with dementia of the Alzheimer type. J Neurol Sci 1984;63:167-72.

17 Cramer H, Kohler J, Oepen G, Shomburg G, Schröter E. Huntington's chorea-measurements of somatostatin, substance $P$ and cyclic nucleotides in the cerebrospinal fluid. J Neurol 1981;225:183-7.
18 Sörensen KV, Cristensen SE, Dupont E, Hansen AP, Pedersen E, Örskov H. Low somatostatin content in cerebrospinal fluid in multiple sclerosis-an indicator of disease activity? Acta Neurol Scand 1980;61:186-91.

19 Rubinow DR, Gold PW, Post RM, et al. CSF somatostatin in affective illness. Acta Gen Psychiatr 1983; 40:409-12.

20 Hoehn MM, Yahr MD. Parkinsonism: onset, progression and mortality. Neurology 1967;17:427-42.

21 Hughes CP, Berg L, Danziger WL, Coben LA, Martin RL. A new clinical scale for the staging of dementia. Br J Psychiatry 1982;140:566-72.

22 Hamilton M. A rating scale for depression. $J$ Neurol Neurosurg Psychiatry 1960;23:56-62.

23 Ellman GL, Courtney DK, Anders V Jr, Featherstone RM. A new and rapid colorimetric determination of acetylcholinesterase activity. Biochem Pharmacol 1961;7:88-95.

24 Mefford IN. Application of high performance liquid chromatography with electrochemical detection to neurochemical analysis: measurement of catecholamines, serotonin and metabolites in rat brain. J Neurosci Methods 1981;3:207-24.

25 Hornykiewicz O, Kish SJ. Neurochemical basis of dementia in Parkinson's disease. Can J Neurol Sci 1984;11:185-90.

26 Appleyard ME, Smith AD, Wilcock GK, Esiri MM. Decreased CSF acetylcholinesterase activity in Alzheimer's disease. Lancet 1983;ii:452.

27 Pezzoli G, Panerai AE, Di Giulio A, Longo A, Passerini D, Carenzi A. Methione-enkephalin, substance $P$, and homovanillic acid in the CSF of Parkinsonian patients. Neurology 1984;34:516-9. 